\title{
THE NEED OF LOCAL IDENTITY IN POLITICS. THE CASE OF WOMEN MAYORS IN THE NORTH-EAST REGION OF ROMANIA
}

\author{
Andreea Daniela FEDOR \\ Alexandru Ioan Cuza University of Iași, Faculty of Geography and Geology, ROMANIA \\ andreea.fedor@yahoo.com
}

Corneliu IAȚU

Alexandru Ioan Cuza University of Iași, Faculty of Geography and Geology, ROMANIA corneliu.iatu@gmail.com

\author{
Marinela ISTRATE \\ Alexandru Ioan Cuza University of Iași, Faculty of Geography and Geology, ROMANIA \\ marinelaistrate75@yahoo.com
}

DOI: http://doi.org/10.23740/TID120194

\section{ABSTRACT}

Women's involvement in politics is a complex and multidimensional phenomenon in Romania, following very contradictory and sinuous trends: starting from a high rate of female participation in the political life during the Communism (only as representatives, but not as decision-makers), to an abrupt drop in the 1990s, when politics was male-dominated, to, finally, a rise of female presence in this field, especially when Romania joined EU. Given these premises, the study aims to offer an overview on women's representation in politics at local level, for the 2016 elections, and to understand if there is a connection between the local identity of a future female candidate within the community and her success during the electoral campaign; we have tried to identify the key elements, if any, for a greater presence of women in the politics and if any gender stereotypes are manifested in the studied rural communities; estimating the Romania's probability to have, in the more or less distant future, a greater presence of women in political life, both in urban and rural areas.

Keywords: political identity, women, local administration, elections

\section{INTRODUCTION}

Gender equality is an important topic found in all European countries, in all political discourses and in the Charter of Fundamental Rights of the European Union, as an attempt to ensure that this principle, which has become a real mark of Europe, works not only at the EU level, but also at a national and local level. But there are still significant differences between the European discourse and the daily political life. Women's participation in political life is a complex process, multidimensional, determined by the electoral system of each country, the level of economic development, cultural heritage and barriers present in all environments, being at the same time, a natural consequence of socio-economic conditions and a sequel of gender segregation within the labour market, with all the consequences that derive from these (gender pay gap, feminization of poverty, etc.) (Cickaric, 2015). The concern about the women's involvement in 
the political life is part of the same trend that occurred in the academic and political environment after 1990, regarding the measurement of gender inequalities, when it became obvious that there is a strong connection between them and the economic growth (Dollar \& Gatti, 1999). Firstly, in order to mitigate gender inequalities, it is necessary to know the causes that lead to their emergence, increase and perpetuation, and then to find solutions for measuring gender inequality (Branisa, Klasen \& Ziegler, 2009). The interest in studying the women's involvement in public life can be observed in different fields of social and human sciences (anthropology, political science, sociology, human geography, economics) (O'Brien, 2009; Istrate, 2012; Wittemer \& Bouche, 2013) which facilitates the interdisciplinary dialogue and identification of key issues (gender, as well as ethnic, economic or religious segregation). Yet, it should be added that Geography seems to transform more slowly than other disciplines that have already "embraced" gender studies (Timár \& Fekete, 2010), despite the fact that it is a discipline that has been extensively studied in Eastern countries.

The increase of the degree of women's participation in political life since the 1990s led to the existence of various studies dedicated to this subject. There are numerous works studying the phenomenon of the women's insertion in the political life within the Central and Eastern Europe countries, which faced a dramatic decrease in the number of women in Parliament and Government in the 1990s, after which they increased again, especially due to the harmonization of the legislation with the European one, to which they joined (Băluţă, Dragolea \& lancu, 2007; Cernat, 2010; Stegmaier, Tosun \& Vlachova, 2014; Gârboni, 2014). The new electoral laws in Europe offer opportunities for women (gender quotas), but do not guarantee that women will be elected. In this respect, Poland, Belgium, France, Portugal, Slovenia and Spain as countries with legal quotas, have lower presence of women in politics compared to other countries where there are no imposed quotas (Finland) (Millard, 2014). Beside the legislative initiatives, there are voluntary party quotas and civil society initiatives that fight for a better representation of women. Yet, the optimal conditions for increasing women's political presence occur when political women, feminists within governing institutions and civil society activists coalesce to pursue this goal (Galligan, 2006).

Western European countries, although they have taken important steps in this direction and women are encouraged to participate, get involved, still face an underrepresentation of women in political life (Esteve-Volart \& Bagues, 2012).

The results of different researches draw attention to gender discrimination that is manifested in politics, women being seen especially through their role as wives, mothers, daughters, more compatible with the private sphere and less with the role of political leaders (Clavero \& Galligan, 2005). Although often the presence of women in politics is linked to a lower degree of corruption, and voters are less suspicious that a female candidate would defraud elections, they continue to be less voted. Women are perceived as being more honest, ethically and more concerned about the well-being of the community (Barnes \& Beaulieu, 2014). As such, it was empirically demonstrated within 18 European countries that the higher the levels of corruption, the lower the quota of elected women is, showing that there is a correlation between EQI (European Quality of Government Index) and the share of women elected to local councils throughout Europe (Sundstrom \& Wängnerud, 2016). In 2001, the European Parliament argued that women's inclusion in decision-making strengthens democracy and is a necessary condition for women's interests and concerns to be taken into account. In what concerns the women's representation within EU, Sweden and Finland are at the top, though only Sweden has over $40 \%$ of women in local and municipal councils. Romania, Cyprus, Greece and Croatia are at the bottom with below $20 \%$ of women participating (Shreeves, Prpic \& Claros, 2019). In a study 
conducted in 2008, Emanuela Lombardo captures different aspects of the political frameworks on the under-representation of women in politics in the EU and Spain: while EU documents seem to be particularly concerned about reaching or not reaching the targets set in terms of the number of women in the elected and decision-making bodies, the Spanish documents focus on women's quotas in politics, the problem being presented either as a positive or negative assessment of quotas as a way to obtain a higher representation of women (Lombardo, 2008).

Feminist political theorists have thus countered the discursive marginalization of women as somehow less political than men, by drawing attention to the restrictive understandings of political participation and the political sphere that underpinned it (Norris \& Lovenduski, 1993). This is why many women tend to engage with issues at the local government level, a fact demonstrated also in a study conducted for the Council of Europe, rather than in national legislatures (Einhorn, 2006).

Different types of identity (place, urban, regional, national, cultural, personal, community and landscape) have been proven to contribute to the identity of a local place (Shao, Lange \& Thwaites, 2017) as the identity of a place is viewed in relation to the historical heritage and the traditional characteristics of the region (Deffner, 2007). At the same time, local identity harbours emotional and symbolic meanings people ascribe to a sense of self and attachment to place (Tartaglia \& Rollero, 2010).

While considering the context-specific issues of particular regions, it is needed to understand the realities of lives embedded in distinct localities. Broad statistical generalizations are insufficient for constructive conceptualization, but the addition of oral histories and empirical field data allows us to link the local and the global through the individuals' voices, bringing a new understanding to gender and development (Momsen, 2003).

\section{OBJECTIVES AND METHODOLOGY}

The aim of this article was to capture an overview of the women's representation in politics at local level and to understand if there was a connection between the local identity and the success during the electoral campaign. Besides, we have tried to understand if certain gender stereotypes are manifested within the studied communities and to identify, if present, the main key elements for a greater presence of women in political life especially in the rural areas. Being a study that presents a geographical perspective on gender studies, we should mention that quality/quantity conflict is also admitted by geographical subjects that prefer a more consistent leaning towards the qualitative ones, i.e. gender studies relying on emphasizing the reflective, subjective and personal aspects, contextual knowledge and specific experiences (McDowell, 2002). Not giving up the quantitative approach, geographers recognize the difficulty to approach the gender topics, particularly due to insufficient database selectively collected (Ortiz, 2004).

This work has two distinct parts:

(a) Qualitative speech on women in leading positions and the political life within the Romanian society: women during the Communist era and its discourse regarding gender equality, women in the Romanian society after 1989, identity sketch of a woman-president or mayor and perceptions on women president or mayor. 
(b) A case study in the North Eastern Region of Romania. Interpretation of the interviews' results that were applied to 11 female mayors from rural areas, in Botoșani, Iași, Vaslui, Neamt, and Bacău counties.

In this way, it was possible to understand the female mayors' perception on their work, the problems they faced and get a look on "the other side of the barricade", not only on the voters' perception on women involved in politics.

The research area and the analysis scale were defined and delimited; a database was created, these were taken from the national electoral authority (Central Electoral Bureau), the National Institute of Statistics and the 2011 Population Census.

The method used for the second part of the paper was that of the interview, one of the most used methods in qualitative research (Zamfir \& Vlăsceanu, 1998). The interview was conducted, structured and addressed to a specially selected category, according to certain criteria - female mayors in rural areas, respectively. The interview consisted in a set of logically ordered questions, which allowed the collection of objective data (age, gender, level of education, etc.) and especially subjective (attitudes, opinions, etc.). The questions focused on the reasons of choosing this career path, on investigating the possible mechanisms behind these motivations, correlations with factors such as family support or citizens' attitude and highlighting the importance of factors such as cultural context, regional particularities, gender issues, etc. All interview-partners gave us their consent to use the questionnaire for scientific purposes. In order to respect their confidentiality, the " $R$ " symbol (respondents) was used in the results analysis, and the number (1-11) represents the order in which the meetings were conducted (R1 - R11).

We must emphasize that we cannot claim that the results of this approach are representative at national level or for the entire population of women mayor of Romania. The results should be used as such and only for the purpose of explaining certain behaviours that manifest within the research group. The main criteria considered for selecting the communities in which the interviews were conducted are the geographical and proximity (North-East Development Region) as well as residential (respectively rural) areas. The selection of the respondents was made according to the access we had to the respective city hall and, crucially, the availability of the respondents to answer the questions and the kindness to offer their help for scientific research. The final results achieved from this analysis at national and local level were manually processed in Excel. Their territorial interpretation will explain the participation of the spatial component in shaping different attitudes more or less favourable to gender equality (Tudora, Bănică \& Istrate, 2015).

\section{WOMEN IN LEADING POSITIONS AND THE POLITICAL LIFE IN THE ROMANIAN SOCIETY}

Numerous studies carried out both abroad and in Romania have had the political representativeness of the women from the Romanian space as their subject. These refer to several periods: the Communist period (1947-1989), considered a landmark of the promoted doctrine and the way it shaped mentalities, the transition period (1990-2007) and the one after the accession to the European Union. The issues addressed are among the most varied: the involvement / participation of women in politics, the analysis of obstacles that hinder the representation of women in politics, electoral quotas and their effects, descriptive and substantial representation, strategies for parity in political representation, and these are applied during elections at presidential, parliamentary and local level. Following the Revolution, Romania embraced the liberal theory of "the politics of ideas", the one that takes into account 
the ideas of the representatives, coagulated by the political programs, and not their gender or race, which although based on solid arguments, has the defect of not sufficiently covering the issue of women's political exclusion (Phillips, 1995). In order to offer an overview, the literature studies the issues listed above on wider areas, gathering countries that share a common historical substrate. From this point of view, Romania is integrated among the countries with a tradition of the European Central-East type along with Poland, Hungary, Estonia, Latvia, Lithuania, Croatia, Slovakia, Bulgaria, Turkey, Slovenia, and the Czech Republic (Sundström \& Wängnerud, 2016).

\section{Women during the Communist era. The Communist discourse on gender equality}

We cannot deny that the women's condition clearly improved, compared to their status before the Second World War, but we should underline that the concept of gender equality was never really applied during Communist Romania, since the disequilibrium of power exercised by men and women had never been substantially altered (Gal \& Kligman, 2003). The mobilizing discourse promoted during the Communist era, which underlined the threefold role played by the woman (worker, wife, mother) had a great influence in creating a considerable class of women having a professional qualification. Through the implemented policies, the forced elimination of gender differences is wanted, a phenomenon known as gender egalitarianism. The latter facilitated the access of women to education and their insertion on the labour market in order to strengthen the power and create a great and highly-engaged workforce (Ciucă, 2010). Nowadays, this undoubtedly presents an advantage for Romania, although women are still dominated in the fields of public services (education, health, administration) - more stable but low-paid fields.

For example, in 1985, women represented $35 \%$ of the Parliament Members, $17 \%$ of the members of the Great National Assembly and $23 \%$ of the Communist Party members. However, these relatively high percentages do not express an equal involvement of women in the political life, on the contrary (Gârboni, 2014), most of the times women played a role only on the surface, the decisions being taken by men (Turcu, 2009). Thus, until the end of the Communist period, the woman politician was regarded as a symbol of an unrealistic policy, as an object of Communist propaganda. These public perceptions could partly explain the extremely low involvement of women in the political life after the 1990s, right after the fall of Communism.

\section{Women in the Romanian society after 1989}

After the fall of Communism, just like other states in the Centre and Eastern Europe, Romania had to implement a new political system, based on free elections and pluralism. This shift from Communism to Pluralism was generally characterized by ambiguity. Besides, the slow and erratic transition to a market economy, combined with the demands of international lending agencies and the impact of the global recession, has affected the nature of the workforce, welfare policies and government spending (Massino \& Popa, 2015).

If men quickly changed sides and easily entered the political life after 1989, women could not face a similar situation since they were not present as organized, visible and active groups on the political scene. Thus, they rapidly lost ground and their chances to take part in the political life diminished, at least during the first decade after the revolution. Only a few women, former anti-Communist dissidents were involved in politics, as prominent members of the opposition parties or spokespeople in the Prime-Minister's or the President's office. In other words, Romania preserved the same attitude for one more decade after the revolution, the same public 
opinion and political behaviour conceived during the Communist times, namely, to reject/marginalize women in the political life.

It was only at the beginning of 2000 that women gained visibility on the national political scene, becoming ministers or counsellors to the president. Moreover, when the accession to the European Union negotiations had started, a new series of measures regarding the necessity to include women in the political life was imposed. In 2002, the law on gender equality was conceived and enforced, condemning gender discrimination and domestic violence and emphasized the equal right to education and social services, as well as the principle of equal pay for equal work. The need to align with the European Union standards before the Romanian society as a whole recognized the need for a feminist agenda has generated an original type of feminism, which does not necessarily reflect a genuine commitment to the involvement of women in public life, but a supranational demand (Miroiu, 2004; Voina, 2017).

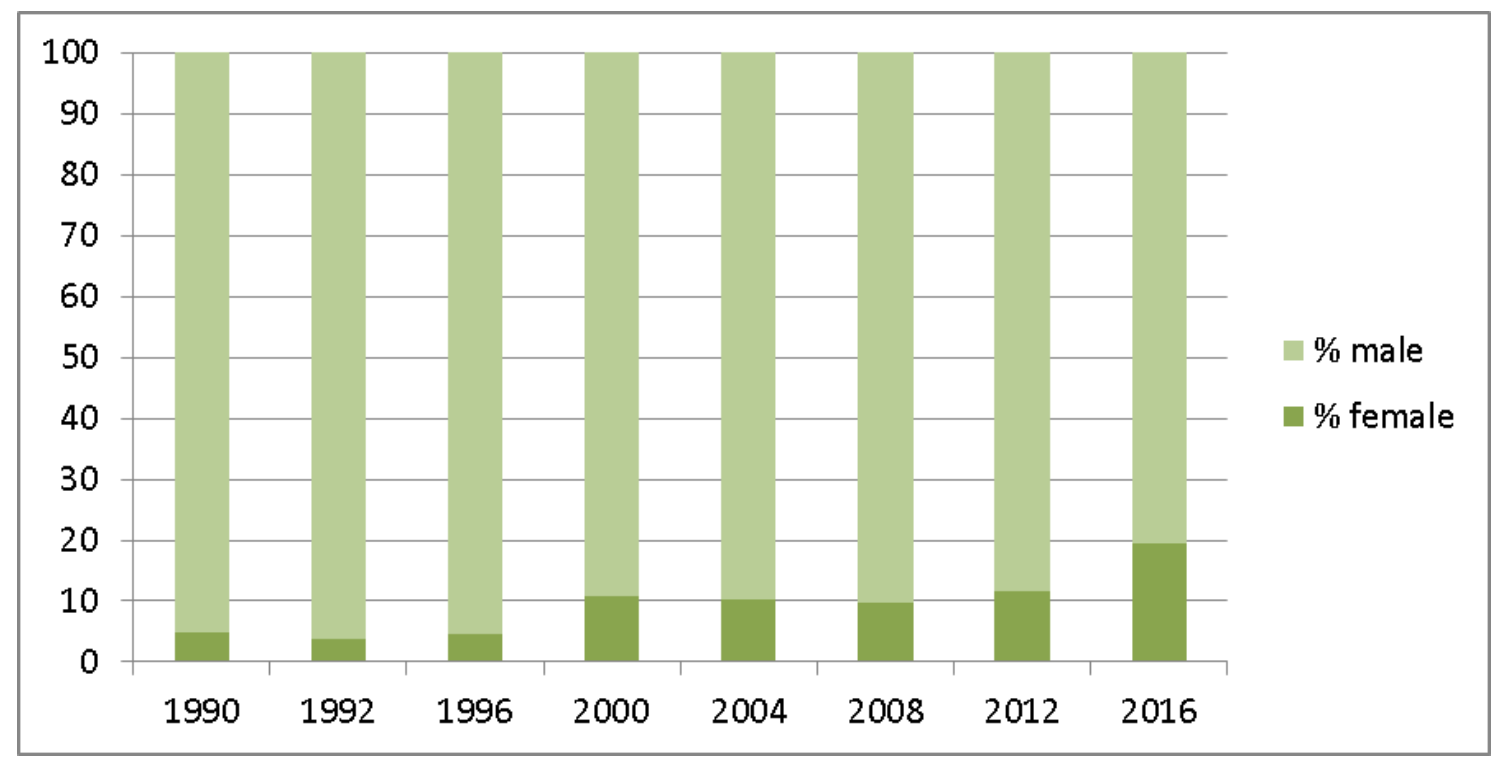

Figure 1: The percentage of women in the Romanian Parliament

Source: http://www.roaep.ro/

Thus, if the legislative bodies which have been in charge since 1990 are analyzed (Figure 1), one can notice the low percentage of women involved in politics, both in Parliament (Chamber of Deputies and Senate) (Matei, laţu \& Vert, 2010) and Government (Gârboni, 2014).

However, the situation is different when women as constituent parts of the Romanian representatives in the European Parliament are analysed (29\% women in the first mandate, $36 \%$ in the second mandate, this last percentage is only a little bigger than the European average of the female Euro-deputies, which is $35 \%$ ). Clearly, the Romanian parties placed women on the eligible places for the elections in the European Parliament as an obvious wish to promote women on external level rather than on the local or national. How could we interpret this openness? Romania adhered to the EU recently, its decisional role is not so important, hence neither the euro-deputy chairs are attractive to the male politicians, since they aim for a major decisional role, as it happens in the national politics. 


\section{Identity sketch of a woman-president or mayor}

According to the Romanian Constitution, men and women have equal rights, but between the legal assertion of rights and their application, there is a considerable distance, especially when it comes to women in politics. They are generally less psychologically prepared to assume such a candidacy, including its consequences (FP Romania, 2012). At the same time, we must note that the women who reach the top are very well prepared, precisely because of the selection process, which is tougher for them, given the conditions of political representation that work today. Among the qualities that a woman who is applying for the president status of a country must have, we mention: the existence of a strong political force behind to ensure her campaign; to gain notoriety, to have been involved in national projects, legislative initiatives with good results, which should already be known by the public; to project the image of an intelligent, but not arrogant, competent, moral person; firm, but without being non-feminine (a feminist approach would strike a principled opposition both from a majority of the male electorate and, to a certain extent, from the female electorate). Regarding the approach of the electoral campaign, it is important that a woman-candidate to ignore the particularity of the gender regardless of the approached strategy, it should not be made any communication reference to the candidate's gender. It would be wrong that the speech, program, actions, to be determined by gender particularity. In the case of a leader, it is not gender that matters, but his/her education, talent, personality, and experience. The quality of being a woman will not give her a competitive advantage.

\section{Perceptions on women presidents}

For obvious reasons, on the one hand, a female presidential candidate starts with a smaller electorate than a male candidate who would have all the necessary assets for such a candidature. On the other hand, we should also consider that the answer to this question has been influenced by the current context of the presidential elections and the real candidatures.

Vintilă Mihăilescu, anthropologist: "In principle and culturally speaking, Romanians are not ready yet for a woman leading the country - even if, in some special cases, this is possible on a local level. On the other hand, the current context is totally atypical and special, the potential of rejection held by the political class is so big that the electorate can cling on any new portrait, anytime, only if it is visible and credible enough. In such a case, the candidate should better be independent and rather technocrat, thus compensating for the feminine weakness by enforcing the mystic of the saviour technocrat" (FP Romania, 2012). The same idea is supported by Darie Cristea, INSCOP project coordinator, who declares that "Romanians are not really prepared for a woman president, not as it is generally believed. It remains to be seen what woman-candidate is needed in order to coagulate the necessary electorate"; "We cannot say that the idea of a woman candidate to the presidential elections is something unheard of for the Romanians. Moreover, Romania has gone through several social campaigns regarding gender equality. Gender equality is socially desirable and recognized as such. At least as discourse, most people are willing to accept women candidates. But for the real attitude...it is rather hard to comprehend" (INSCOP, 2014).

The first woman, after 1990, that chose to run for the presidential position was Graziela Elena Bârla, as independent, in 1996 (Figure 2) and got 0.55\% of the votes (source: Central Electoral Bureau). It took other 18 years till the next candidates run for the presidential position, in 2014 (14.3\% of the total number of candidates): one independent (Monica Macovei), who reached $4.4 \%$ of the votes and another one (Elena Udrea), who was supported by an alliance and scored 
5.2\% (source: Central Electoral Bureau). The distribution of votes received by the two candidates highlights the presence of two axes as well as of two territories which perhaps, by chance or not, rank among the richest regions in Romania which adapted more rapidly to the circuits of transition towards market economy. They were also in advantage due to the position (capital city, the western part of the country, the Pontic seaside), having kept certain strategic industries (Sub-Carpathian Muntenia) or due to the cultural prestige (towns such as Cluj, Iaşi, Constanţa, and their metropolitan areas). At the opposite side, with a reduced number of votes given for women, we can find other regions which showed a traditional approach and a certain degree of conservatism (Eastern Moldavia and most part of the Bărăgan Field, the Southern and SouthWestern part of the country, the North-Western part of Transylvania), expressed in what may be considered as vulnerability (either dynamic, or structural) and these, forced by the demographic pressure and the massive deindustrialisation, witnessed a massive migration of the population, especially young and adult (Istrate et al., 2016).

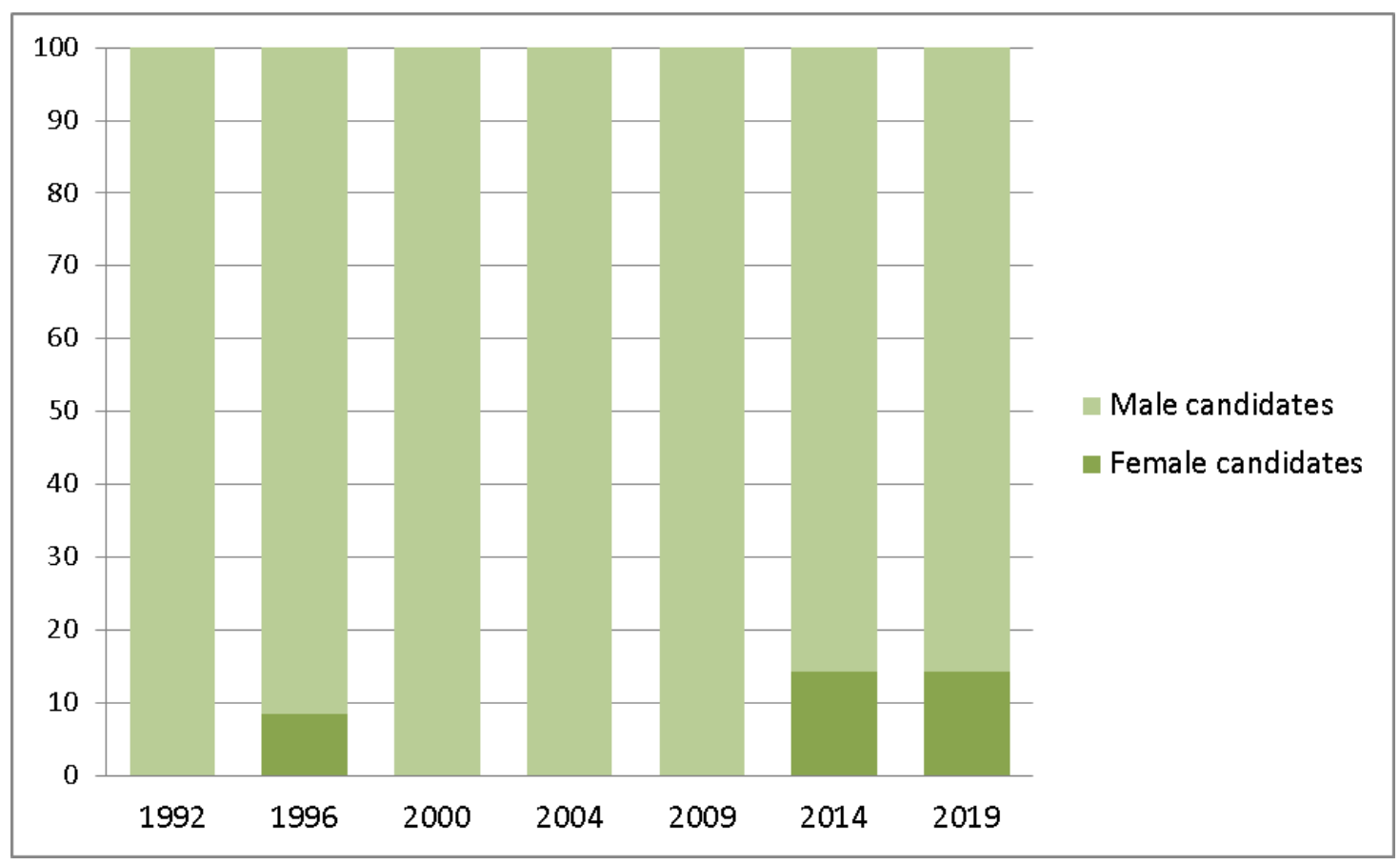

Figure 2: The proportion of the Presidential candidates, by gender, $1992-2019$ Source: http://www.insse.ro/

\section{Perceptions on women mayors}

In order to identify other aspects that allow us to draw the perception of the citizens regarding the involvement of women in politics and their activity as female mayors, it was considered necessary to take into account the opinion of the women from the non-governmental organization Romanian Women's Lobby, member of the European Women's Lobby (EWL), whose activity aims to support gender equality, to promote women's rights in all spheres of public and private life, and economic and social justice for all women. Thus, the president, respectively the vice president of the association was asked to give some opinions regarding the involvement of Romanian women in public life. At the question Is it possible to build a specific identity for women mayors in Romania?, the president of the Romanian Women's Lobby 
answered: "A real analysis is not possible at this particular moment in time, because due to the actual electoral system, in which candidates are running on party lists, and the order on the list is decided by the (local) leaders of the political parties, chances to see women on eligible places are random and rare. This is the main reason we will not find women mayors in the (large) cities of Romania (with very few exceptions). The only place in which the power is sometimes shattered by women who dare to challenge this model is rural space. The reason for this is (as low the percentage of rural women mayor is right now) that the smaller the local communities, the higher the chances for political candidates who run for mayor office to know their community better and see proper solutions. Women who decide to run as mayors for their communities are not doing this for personal reasons. The public good and the inner urgency that things need to change in order to be solved properly and efficiently are forcing the women in local communities to overlook their personal blockages and fight for a good place on the electoral lists. Also chances for women to have their message heard by their audiences is higher in smaller communities, where they do not need (very high) resources to run a good campaign, and need less votes to be elected compared with (bigger) cities. Exceptions to this scenario when women are elected as mayors in big cities are the ones who possess a big image capital (either are well known to the general public by being celebrities before running, or being well known locally for their professional life - reflected on the local/national media as well)".

When asked When will we be able to say that we have a specific identity of women mayor in Romania? she replied: " 1 . When the rules of the elections game will be changed and the decisions regarding eligible places on the lists will not be taken in the 'male only' club. 2 . When the electoral list composition will mirror the population structure of both women and men (and different needs of women everywhere - from rural women, to women with disabilities, to women entrepreneurs, to women facing everyday partner violence). 3 . When the order on the lists will not allow more than two consecutive candidates of the same sex, leaving room for responsible women and men on eligible places".

The vice-president of Romanian Women's Lobby and president of the Association Equal Chances for Women stated "The idea to have a woman in political decision-making positions continues to be controversial. However, a special case is represented by the woman candidate to be elected as mayor. [...] The good news is, and this is precisely due to the stereotypes, that the woman candidate in this case does not have to be a technocrat! It is enough to be a woman: to care about the household or the Town hall's demands, to permanently change the priorities according to the needs of the children and the spouse (or of inhabitants), to successfully implement all her daily projects, the household chores or fulfilling her newly acquired mandate. In short, the 'ordinary' man (not the politicians) will keep an eye on the cleanliness of the house and the way his children look and behave - who, according to the stereotype, is 'the reflection of a woman's duty'. Having this reality in mind, men will be confident that their needs will be on the priority list and, as inhabitants, they will be the first concern of a woman-public servant".

The governance of a community requires a complex set of relationships and connections that are established between the various stakeholders, in other words, the existence of a social capital at the local community level. In order to underline the importance of this, there were two public opinion polls conducted in 2015 and 2016 by accredited public opinion polling institutions on the topic of trust in the local administration and the image that Romanians had of local elections were analysed.

Thus, according to the Barometer of Confidence conducted by IRES in March 2015 on a sample of 1,235 subjects, the Romanians trust the mayoralty, as an institution (only $44 \%$, while $53 \%$ said they had little and very little confidence). Instead, they seem to have more confidence in the 
mayor, as a person ( $52 \%$ show a high level of confidence in the mayor, while $46 \%$ prove little and very little). Half of the Romanians were satisfied with the activity of the Local Administration, they considered that there were proficient people, about the same proportion as in the Central Administration (36\% compared to 37\%) and, in a high proportion (77\%), they considered that the localities need a greater decentralization of power from central to local administration (IRES, 2015).

If it is to analyse the "INSCOP Barometer" of 2016 regarding the local elections (on a sample of 1,063 subjects), the image that Romanians have about elections can be completed (INSCOP, 2016). Hence, $57.7 \%$ of Romanians stated that they are interested in local elections, less than 2 months before the 2016 local elections, while almost $10 \%$ were not interested at all. Romanians do not trust the newly emerged parties in political life, preferring to vote on what they already know. On the other hand, the independent candidates seem to show confidence among the population, more than a third of the Romanians (39.7\%) stating that they would be willing to vote an independent candidate at the local elections, without any connection with the current political parties, while $31.8 \%$ would not vote such a candidate. As for the re-election of the current mayor, $38.3 \%$ of the respondents stated that they will not vote for the current mayor or the current interim mayor, while $37.8 \%$ will do. The function of mayor may cause a rapid erosion of the electoral capital if there are taken decisions that are not in accordance with the needs of a certain segment of population, but at the same time can strengthen the position of the mayor within the community. In contrast, most of the population is uncompromising when it comes to corruption. Thus, when asked if they were interested in voting as a mayor a person who is investigated or tried for such acts, but who is not definitively convicted, $82.6 \%$ of Romanians answered in the negative. Only $8.4 \%$ said they would vote for such a candidate (INSCOP, 2016).

\section{THE IMPORTANCE OF LOCAL IDENTITY IN POLITICS. THE CASE OF WOMEN MAYORS IN THE NORTH - EAST REGION OF ROMANIA}

The results of the elections are the expression of the phenomena that take place at three different levels: national (trust in institutions and politicians, level of corruption), local (activity of institutions, quality of local social environment) and personal (personal and household wellbeing, family condition, satisfaction), compared to the current standard of living and the expected future evolution, etc.

During the last 30 years, the attitudes and values of the Romanians have changed both towards the political events, and the political culture as a whole, this being represented by the interest for the politics, the information, the participation in the elections, the strong presence during the elections, the confidence in the political actors, and political effectiveness (Comșa, 2012). However, the women's involvement in politics is still perceived as a deviation from the traditional male norm and it may take more time until the idea of women in a leading position will not be a surprise ("One day there will be no more women leaders. There will be only leaders" - Schnall, 2013).

In the 2016 local elections (Table 1), only 147 of the 3,187 mayoral mandates at national level were won by women, respectively $4.6 \%$. Of these, 138 mandates were won in rural areas and only 9 in urban areas. The counties with the most terms won by women are Arad and Vaslui with 8 terms each, followed by Bacău, Cluj, Constanţa and Neamţ with 7 each. In Bistriţa-Năsăud, Braşov, Harghita and Timiş counties, no mayoral mandate was won by women (Paul, 2016). 
Table 1: The votes' distribution for female mayors at the local elections in 2016

\begin{tabular}{|l|r|r|r|}
\hline & $\begin{array}{c}\text { No. of female } \\
\text { mayors (urban) }\end{array}$ & $\begin{array}{c}\text { No. of female } \\
\text { mayors (rural) }\end{array}$ & $\begin{array}{c}\% \text { of total } \\
\text { mayors }\end{array}$ \\
\hline Romania & 9 & 138 & 4.61 \\
\hline NE Region & 0 & 36 & 1.12 \\
\hline
\end{tabular}

The North-Eastern urban region of Romania has no female-mayors, but the rural areas of the same region have 36 female mayors, which means $26 \%$ of the total number of female mayors in the rural area at national level (Table 2).

Table 2: The distribution of the female mayors in the North-Eastern Region at local elections in 2016

\begin{tabular}{|c|l|r|r|}
\hline $\begin{array}{c}\text { Rank in the } \\
\text { national hierarchy }\end{array}$ & County & $\begin{array}{c}\text { No. of female } \\
\text { mayors }\end{array}$ & $\begin{array}{c}\text { \% female mayors of total } \\
\text { number of mayors in the county }\end{array}$ \\
\hline 2 & Vaslui & 8 & 9.30 \\
\hline 5 & Neamţ & 7 & 8.43 \\
\hline 6 & Bacau & 7 & 7.53 \\
\hline 10 & Botoşani & 5 & 6.41 \\
\hline 14 & Suceava & 5 & 4.39 \\
\hline 17 & laşi & 4 & 4.08 \\
\hline
\end{tabular}

Data source: Permanent Electoral Authority, 2016

The presence of stereotypical community attitudes, articulated according to religious or traditional customs, generates rigid psycho-behavioural architectures, territorially observable, such as the rejection and / or reluctance towards certain manifestations of women's wishes to play an important official role at community level. Still, in Romania, affective legacies of the communities where the man played the primary role in the society and where the role of the woman is clearly predetermined, if not officially, at least mentally, can still be found; it still captures the way in which the exaggerated involvement of the woman within the family space produces attrition, the impossibility of deciding for her own life and/or the erosion of the woman's integrity and social participation. Symmetrically with these patriarchal areas, modern territorial structures are affirmed, most of them having national connection rates higher than those registered at regional level, signalling their character as regional or even national hub. The current Romanian urban environment, more cosmopolitan and less traditionalistic than the rural world, is much more tertiaryised and seems to favour women. The upgrade of social life preserves the main urban centres, while the north and the south-western area remain tributary to predominantly traditional values (Istrate et al., 2016).

The interest in politics is bigger in the case of people with a higher level of formal education, who generally have higher incomes as well (or at least more stable), who are well-informed, and have a higher level of trust in people and a relatively higher one in politicians. They think that politics has an influence on their lives, they welcome change and are interested in the political 
colour of the candidate/political platform (left, centre, right). The ones with lower level of education also, but not necessary, lower incomes and no relationships (relational capital), are less informed, presenting less trust in people, and are unsatisfied with the way in which democracy and market economy function.

\section{The interview-partners}

During our research, 11 people were interviewed, all women mayor from the rural areas of the North-East Region (Table 3), some being in the first term, others in the second or even the sixth term (the case of George Enescu commune). The interview was conducted by the first author (Andreea Daniela Fedor), from June to August 2018 and in July 2019, being completed individually, the meeting with each respondent taking place in the town hall headquarters. The characteristics of the rural environment taken into account are the following: communes inhabited by farmers and livestock breeders, where jobs have been a rarity, especially after 1990 , and poverty a reality.

Table 3: The demographic characteristics of the studied administrative units and the electoral situation at the 2016 elections

\begin{tabular}{|l|l|l|r|r|r|}
\hline $\begin{array}{l}\text { Interview } \\
\text {-partner }\end{array}$ & Commune & County & $\begin{array}{l}\text { The total } \\
\text { population of } \\
\text { the commune } \\
\text { (2016) }\end{array}$ & $\begin{array}{l}\text { Voting } \\
\text { presence } \\
\text { (\% of the } \\
\text { voters) }\end{array}$ & $\begin{array}{l}\text { The percentage } \\
\text { scored by the } \\
\text { female mayor (\% of } \\
\text { the ones that voted) }\end{array}$ \\
\hline R1 & G. Enescu & Botoșani & 3,255 & 26.12 & 43.34 \\
\hline R2 & Grivița & Vaslui & 3,672 & 34.57 & 65.61 \\
\hline R3 & Poduri & Bacău & 6,509 & 21.12 & 43.90 \\
\hline R4 & Tamași & Bacău & 3,096 & 46.17 & 44.93 \\
\hline R5 & Filipeni & Bacău & 2,278 & 29.60 & 66.60 \\
\hline R6 & Strunga & lași & 4,443 & 29.23 & 55.18 \\
\hline R7 & Tașca & Neamț & 2,619 & 31.36 & 44.97 \\
\hline R8 & Săbăoani & Neamț & 11,863 & 20.06 & 43.51 \\
\hline R9 & Pîrgărești & Bacău & 4,869 & 18.93 & 43.34 \\
\hline R10 & Vf. Câmpului & Botoșani & 3,443 & 27.63 & \\
\hline R11 & Ciortești & lași & 4,268 & 23.81 & \\
\hline
\end{tabular}

Source: INSSE and http://www.2016bec.ro/statistici/index.html

The size of the studied administrative units varies between 3,255 and over 11,000 inhabitants, therefore to large and medium-sized rural administrative units, an important aspect if we consider that the communities with larger stocks of demographic and social capital, theoretically, have better results in terms of economic, political and social development. The interest in politics differs depending on the size of the locality (Baglioni, 2007), increasing with the decrease in size of the locality due to the increased number of interactions with public institutions, while the presence / involvement of the mayor is more easily felt.

The 51.8 years average age of the interview-partners (min. 32 and max. 67 years) shows that the female mayors are mature, experienced people, capable of meeting the demands of such a 
position. Other qualities: expertise in the local administration, "dealing" with the problems of a community, as well as an open-minded, faithful, role model mother, and reliable friend.

\section{Q1: Which was your professional background?}

Most of the interview-partners were highly-educated, often working as a teacher in the rural area, economist or agronomist. However, there were also two examples in which they reached the administrative top, from the public execution officer to secretary of the commune who won the elections. Not in a few cases, the female mayors were born, raised and educated in the respective locality, as well as their husbands, which was perceived as an advantage and helped them during the elections. They were well-known people within the local community, showing professional prestige, high morality and the citizens trusted them as they proved higher confidence in the local policy representative, represented by the mayor and the city hall, while the central political institutions were perceived as being at a greater social distance and less interested in the people's real needs. Once again, it is confirmed that the term "local" implies identity and common interests, sense of belonging, shared history and the connection between the citizens who form the community (Teles, 2012; Banini, 2017). A strong relationship between citizens, on the one hand, and local leaders and institutions, on the other, shows an increased interest in community development and the creation of a common future.

\section{Q2: Which was the motivation behind your decision to candidate for the mayor position?}

Some of the interview-partners stated that the desire to do something for the community even better than the former mayors did was their main motivation ("I felt I could do more than the mayors who were before me", "I knew I could contribute to the development of the commune"). Their previous experience, either as a school principal or as a manager in other fields of activity, made them trust their strengths and demonstrated their skill, creativity and seriousness as a mayor ("I came from a well-organized system and I had the impression that I was in a chaos here. I considered that I had the necessary experience"). The answers come to confirm, once again, the idea that the higher the level of formal education of women, the more their willing to participate in political life, to run for and hold leadership positions (Sahu \& Yadav, 2018).

In addition, the facts that they were aware of the problems that the local community was facing and were encouraged by citizens were the main reasons that made them overcome their hesitation and run for the elections ("Living within the community whose problems I knew and the way I could solve them", "I did not want to run for the elections. When the former mayor left, the community asked me to run for the elections").

Why are we committed, why are we involved in community life? The answer to this question will allow us to better understand the participatory mechanisms. By trying to highlight the factors that facilitate the participation in local public life, Lowndes, Pratchett \& Stoker (2006) show that people are committed to do something when they have the right skills and resources, when they have a sense of belonging to a particular community, when they are encouraged and believe that their involvement will make the difference, as the answers above demonstrate it. 
Q3: Who supported your candidacy?

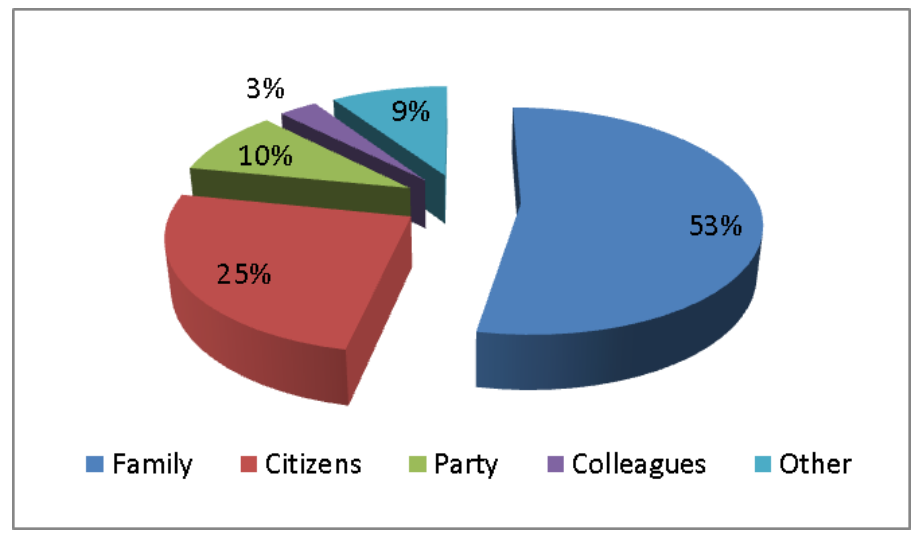

Figure 3: Who supported your candidacy?

Data source: The interview

The family's role is very important, especially in rural communities (Figure 3). If you have the family's support you can get involved in the political life, as well as when you do not have children or they are adults, went to school or founded their own family ("If I had young children I would not be a candidate. As a mayor you must be available $24 / 24$ "). The mayor is not only judged by his/her own intrinsic qualities, but also from the family perspective (husband, children) and the extended family, especially if they live in the same community. At the local level, the person and his/her reputation and of his/her family, the communication with the citizens, the trust they show in the mayor are the most important, and less the party to which he/she belongs. In fact, almost three quarters of the respondents $(72.7 \%$, with the mention that one is independent) considered that they would have won the elections without the party's support, but it depends, however, on the party you belong to, whether you are nominated or not ("Your reputation and the way people perceive you weighs heavily for my party because our leaders receive feedback; if you have influence within the local community, they invite you to run for elections"). Overall, although at the declarative level people mention that gender does not matter, but the personal and professional qualities of the chosen one, the analysis of the data allowed us to highlight that a woman cannot successfully apply if she does not have the support / consent of the family, while for a male candidate this is relatively unimportant.

Q4: Do you consider the candidate's gender to be relevant in the political ascension? Please motivate your answer.

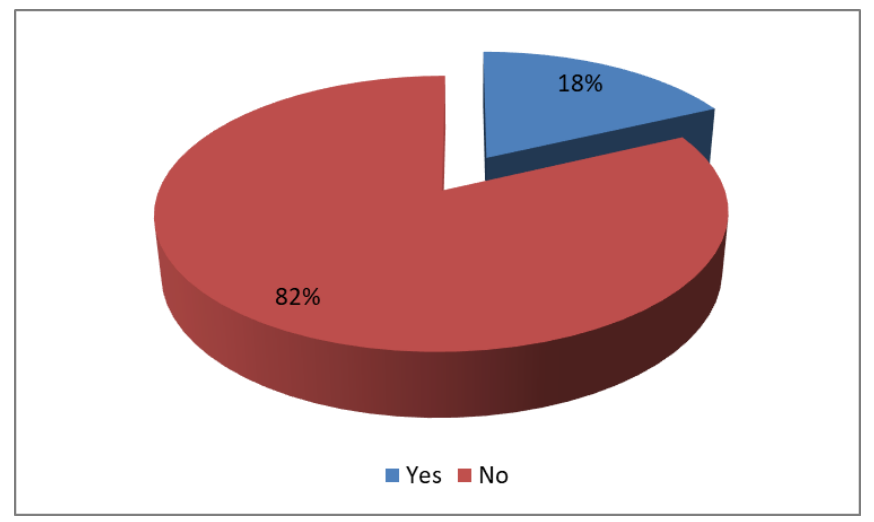

Figure 4: Do you consider the candidate's gender to be relevant in the political ascension? 
$82 \%$ of the interview-partners affirmed that the gender is not relevant, at least not at this level, for mayor in a rural community (Figure 4). The candidates' professionalism and seriousness as well as the qualities they have are very important ("If you are good, you can make a career regardless of gender", "It is difficult, but not impossible if you are a good organizer and administrator"). Morality is also very important (see family connection in the answers above, these two being closely linked) ("Morality is important in a community, to be a model in the community through the example of your family"). However, three of the respondents answered positively for the gender: "Because men are promoted and there is still the conception that the woman should sit in the tub and raise the children", mayor since 2000). It also depends on the local mentality: "In some communities yes, in some communities no. For example, I have met people who say that women are not good as mayor", says one interview-partner. A certain degree of scepticism can be observed when a woman is in a leading position, there is a certain factor of dislike and distrust among the citizens, a fact theorized by Schnall (2013), which notes that women leaders are subjected to further examination just because they are women.

\section{Q5: Do you have difficulties in the relationship with the citizens? Please motivate your answer.}

None of the interview-partners consider that they have any difficulties. The key to a good relationship with the citizens seems to be communication, respect, the effort to listen to them and to solve their problems. Also, the experience in working with a diverse population is important, especially when the previous job was, for example, the teacher at the school in the commune ("as a teacher I interacted a lot with the students and their parents"), but also the transparency, the modesty and the availability offer you time to listen to each other ("I am open, I introduced them what I do", "The approaches are different ... when you have projects you are gone, when you have no projects you stay in the town hall and tell stories"). Of course, there is no agreement, people may be dissatisfied for different reasons, either by the mentality ("I generally communicate well with them, there are some elderly citizens who do not accept that a woman is their mayor") or they are political supporters of former candidates ("I see a poor communication with the supporters of the former mayors"). Successful participation in local government is about the ability to make decisions, of acquiring a democratic leadership, realistic but also empathetic, as opposed to selfish motivation, dependence on subsidies, privileges and protection of the group of which you belong. Moreover, there are, especially in the American literature (Jamieson, 1997), extensive discussions about a particular rhetorical strategy successfully used by women, the so-called storytelling, that uses the narrative discourse as a means of confession, establishing a relationship with the audience and create a sense of reciprocity, which generates a sense of commitment and an ethic of care.

Q6: Do you have difficulties in the relationship with the subordinates/colleagues? Please motivate your answer.

As at the above question, the answers are unanimously negative and the best terms of describing the relationship with the colleagues were: "team", "as a family", "collectively united", "We are equal", "everyone knows what to do", "It's a kind of partnership". But this situation did not come by itself, it had to be built with patience, tact, discipline and personal example ("At the beginning of the term I held a meeting and I told them what I wanted, I asked them to respect the work program ( $8-16)$ ", "If you know what you have to do, clearly define the tasks and use the right communication channels, people understand what they have to do"). 


\section{Q7: Why would you recommend / encourage other women to run for mayor?}

Most of the answers included qualities as: determined, conscientious, balanced, persevering, ambitious, or realistic. They pour their soul into being more sensitive to the social problems of the community, they are also involved in aspects of social life, which requires a lot in the rural area. Intervention in families with young children and old people requires a lot of empathy and affection. "Because I know that women are having a hard time in the house and, definitely, if you can lead a family, you can lead a community, too. The mayor must be both a householder at home and of the community. You are an example."

Q8: There are few women that run for mayor. What do you think are the causes of the small number of female candidates in local politics?

The children and the family are the most frequently cited reasons. Then the constant denigration not only by the media but also by the other candidates ("It's hard in a 30-day campaign to fight with men", "I think that because of the way the electoral campaigns are conducted, at least until 2016 they were a disaster. They (the women) are not strong enough to overcome the insults and denigrations that are brought to them. Women do not like this fight with men, they prefer to stay in the shade. And, finally, the stress felt and the lack of support from the party: the stress you accumulate in this position, as well as the pressure of full responsibility. Men care less").

The answers received by us are specific to the Romanian political culture, where three types of support for the integration of women into the political life can be identified (Pârvulescu, 2019): the traditional type, where the population does not quite understand the meaning of women's involvement in politics and considers that this state of affairs is alien to the nature of things, but accepts it, especially because the EU demands it; the second type, more egalitarian, considers that it is reasonable to increase the political representation of women as a reflection of their demographic weight; finally, the third type considers that increasing women's participation in political life causes beneficial changes in decision-making, ethos and priorities.

\section{CONCLUSIONS}

A democratic system is evaluated according to the degree of representation of all citizens in the decision-making structures, under the conditions which state that a true democracy is based on political competition, transparency, meritocracy and competence. If an important part of the electorate is not constantly represented at all levels, we cannot speak of equality and the consolidation of the gender balance in society (Terzi-Barbaroşie, 2013). During the last three decades, there is a feminization of the middle levels (especially the central level) within the public administration in Romania, while the pyramid of political power is dominated both at the top (at central level) and at the bottom (at local level) by men. Beyond the rising figures for women's participation in decision making, it would be interesting to estimate their actual participation in de facto decision-making.

The political participation of women is influenced by various factors, from knowing and claiming the rights to self-confidence and economic independence. Despite the false encouragement of women to participate in political life, there are still negative stereotypes regarding the role of women in the family and in public life in Romania, these being overloaded with domestic activities even if they have a job, while being engaged in developing their career, as well as their 
partners. However, a slight improvement can be seen both in the collective perception, and within the legal frame. Generally, Romanians are not against a woman leading the country or against a woman having an important position in the political life, but it depends a lot on the female candidate's profile.

The presence of stereotypical community attitudes expressed according to religious or traditional customs generates rigid psychological and behavioural traits which can be noticed in different regions, as well as the rejection or reluctance towards the wishes expressed by women to play an important official role in the community. In Romania, one may still find the traditional way of thinking of the communities in which men played the primordial role in society and women had a clearly established role, if not officially, at least mentally. It is still surprising to see the way the exaggerated involvement of the woman in the family leads to the impossibility to make decisions about her own life and/or eroding her integrity and social involvement.

Women have gained many freedoms after 1990, including the freedom of speech. Their economic concerns often exceed those of motherhood which is figured on birth rates. A logical question can also be asked from this perspective: Why are not women more involved in politics? Maybe because they do not believe in politics enough. Perhaps they are more pragmatic than men in this regard. Maybe they feel more useful in other areas. This perspective can be relied upon to a certain extent.

As for the women already involved in the political life, respectively the 11 female-mayors interviewed, these correspond to the ideal image of the woman who can have a say in public life, according to most Romanians: they had a career before becoming a mayor, they have a supportive family, they know the problems of their community and they want to fight to solve them. Despite the economic and living standards lagging behind, the North-Eastern region is, however, a permissive space leading to the promotion of women, with $26 \%$ of the women mayor in Romania being elected in the six counties of the region, as presented above, the counties in the North-Eastern Region being in the first half of the national ranking.

The current political class, as well as the non-governmental organizations, must encourage young people to participate in political activities and improve their access to the development of leadership skills as well as their potential, to promote successful female figures in the political field and to contribute to enhancing the overall political culture of the citizens by media.

\section{Author Contributions}

Andreea Daniela Fedor worked on building the database, introduction and the interpretation of the results, Corneliu laţu contributed to the result analysis, discussions and conclusions, and Marinela Istrate contributed to the theoretical framework, database, methodology and results of the study.

\section{Acknowledgments}

This work was supported by a grant from the Ministry of Research and Innovation, CNCS - UEFISCDI, project number PN-III-P4-ID-PCCF-2016-0166, within PNCDI III project ReGrowEU - Advancing groundbreaking research in regional growth and development theories, through a resilience approach: towards a convergent, balanced and sustainable European Union.

\section{Conflict of Interest}

The authors declare no conflict of interest. 


\section{REFERENCES}

\section{AUTORITATEA ELECTORALA PERMANENTĂ [PERMANENT ELECTORAL AUTHORITY], http://www.roaep.ro/}

BAGLIONI, S. (2007). The Effects of Direct Democracy and City Size on Political Participation: The Swiss Case. In Zittel, T., \& Fuchs, D. (eds.), Participatory Democracy and Political Participation (pp. 91-106). New York: Routledge/ECPR.

BĂLUȚĂ, O., DRAGOLEA, A., \& IANCU, A. (2007). Gen și interese politice [Gender and Political Interests]. lași: Polirom.

BANINI, T. (2017). Proposing a Theoretical Framework for Local Territorial Identities: Concepts, Questions and Pitfalls. Territorial Identity and Development, 2(2), 16-23.

BARNES, T., \& BEAULIEU, E. (2014). Gender Stereotypes and Corruption: How Candidates Affect Perceptions of Election Fraud. Politics \& Gender, 10(3), 365-391.

BRANISA, B., KLASEN, S., \& ZIEGLER, M. (2009). New Measures of Gender Inequality: The Social Institutions and Gender Index (SIGI) and Its Subindices. Courant Research Centre Poverty, Equity, and Growth Discussion Paper, 10, University of Gottingen, Germany.

BREITENBACH, E., \& GALLIGAN, Y. (2006). Measuring Gender Equality: Reflecting on Experiences and Challenges in the UK and Ireland. Policy \& Politics, 34(4), 597-614.

CERNAT, V. (2010). Socio-economic Status and Political Support in Post-communist Romania. Communist and PostCommunist Studies, 43, 43-50.

CICKARIC, L. (2015). Reconsidering Gender and Women in Politics. South European Journal of Political Science, 3(2), $\begin{array}{lllll}\text { Retrieved } 12 & \text { June } & \text { from }\end{array}$ https://www.researchgate.net/publication/293891494_Reconsidering_Gender_and_Women_in_Politics/cit ations

CIUCĂ, O.L. (2010). Etapele ideologizării conceptului de emancipare a femeii [The Ideologization Stages of the Concept of Woman's Emancipation]. Antropomedia, 74-90.

CLAVERO, S., \& GALLIGAN, Y. (2005). "A Job in Politics Is Not for Women”: Analysing Barriers to Women's Political Representation in CEE. Csech Sociological Review, 41(6), 979-1004.

COMȘA, M. (2012). Opinia publică despre România politică [Public Opinion about Political Romania]. In: Rotariu, T., \& Voineagu, V. (coord.), Inerție și Schimbare (pp. 361-406). Iași: Polirom.

DEFFNER, A. (2007). Place Marketing, Local Identity and Cultural Planning: The CultMark INTERREG IIIC Project. Discussion Paper Series, 13, 367-380.

DOLLAR, D., \& GATTI, R. (1999). Gender Inequality, Income and Growth: Are Good Times Good for Women? The World Bank: Development Research Group. Washington: Mimeo.

EINHORN, B. (2006). Gender(ed) Politics in Central and Eastern Europe. Journal of Global Ethics, 2(2), 139-162.

ESTEVE-VOLART, B., \& BAGUES, M. (2012). Are Women Pawns in the Political Game? Evidence from Elections to the Spanish Senate. Journal of Public Economics, 96, 387-399.

Foreign Policy Romania, September - October 2012, 64-71. Retrieved 21 July 2018, from https://adevarul.ro/international/foreign-policy/

GAL, S., \& KLIGMAN, G. (2003). Politicile de gen în perioada postsocialistă [Gender Politics in the Post-socialist Period]. Iași: Polirom.

GÂRBONI, E.S. (2014). Women in Politics during the Romanian Transition. Procedia - Social and Behavioral Sciences 163, 247-257.

INSCOP Research [INSCOP] [INSTITUTE FOR PUBLIC OPINION POLLING AND RESEARCH] (2014). Barometrul realizat de INSCOP Research la comanda ziarului „Adevărul”, septembrie 2014 [The Barometer Realised by INSCOP Research at the Command of the Newspaper "Adevărul", September 2014]. Retrieved 22 May 2019, from https://adevarul.ro/news/politica/sondaj-roman-doi-vota-femeie--presedinte

INSCOP Research [INSCOP] [INSTITUTE FOR PUBLIC OPINION POLLING AND RESEARCH] (2016). Aprilie 2016 - Alegeri locale [April 2016 - Local Elections]. Retrieved 22 May 2019, from https://www.inscop.ro/aprilie-2016alegerile-locale/ 
INSTITUTUL NATIONAL DE STATISTICA [INS] [NATIONAL INSTITUTE OF STATISTICS], http://www.insse.ro/

INSTITUTUL ROMAN PENTRU EVALUARE SI STRATEGIE [IRES] [ROMANIAN INSTITUTE FOR EVALUATION AND STRATEGY] (2015). Barometrul Încrederii în Instituții. Partea a Doua: Administraţia Locală [Institutional Trust Barometer. Part Two: Local Administration]. Retrieved 22 May 2019, from http://www.ires.com.ro/articol/296/barometrul-increderii--n-institu\%C8\%9Bii.-partea-a-doua:administratia-locala

ISTRATE, C. (2012). Gender Issues in Romanian Accounting Profession. Review of Economic and Business Studies, 5(2), 21-46.

ISTRATE, M., JABA, E., ROBU, I.B., \& BĂLAN, C. (2016). Is Romania Ready for a Woman President? A Statistical Territorial Approach of the Results of the Presidential Elections in 2014. 4th International Multidisciplinary Scientific Conference on Social Sciences and Arts SGEM 2017, Conference Proceedings, vol. I, 115-122.

JAMIESON, K.H. (1995). Beyond the Double Bind. Women and Leadership. Oxford: Oxford University Press.

LOMBARDO, E. (2008). Gender Inequality in Politics. International Feminist Journal of Politics, 10(1), 78-96.

LOWNDES, V., PRATCHETT, L., \& STOKER, G. (2006). Diagnosing and Remedying the Failings of Official Participation Schemes: The CLEAR Framework. Social Policy and Society, 5(2), 281-91.

MASSINO, J., \& POPA, R.M. (2015). The Good, the Bad, and the Ambiguous: Women and the Transition from Communism to Pluralism in Romania. In: Hassenstab, C.M. (ed.), Gender (In)equality and Gender Politics in Southeastern Europe (pp. 171-191). London: Palgrave Macmillan.

MATEI, E., IATU, C., \& VERT, C. (2010). Romanian Woman Involvement in Governance after 1990. Geographica Pannonica, 14(1), 1-13.

McDOWELL, L. (2002). Geographers and Sexual Difference: Feminist Contributions. In: Johnston, R., \& Williams, M. (eds.), A Century of British Geography. Oxford: Oxford University Press.

MILLARD, F. (2014). Not Much Happened: The Impact of Gender Quotas in Poland. Communist and Post-Communist Studies, 47, 1-11.

MIROIU, M. (2004). Drumul către autonomie. Teorii politice feministe [The Road to Autonomy. Feminist Political Theories]. Iaşi: Polirom.

MOMSEN, J. (2003). Gender and Development. London: Routledge.

NORRIS, P., \& LOVENDUSKI, J. (1993). 'If Only More Candidates Came Forward': Supply-Side Explanations of Candidate Selection in Britain. British Journal of Political Science, 23(3), 373-408.

O'BRIEN, J. (ed.) (2009). Encyclopedia of Gender and Society, vol. 1. Thousand Oaks, California: SAGE Publications.

ORTIZ, A. (2004). Gènere, Espais públics i Construcció dels Sentit de Pertinença a Barcelona [Gender, Public Spaces and the Construction of the Sense of Belonging to Barcelona], PhD thesis, Department of Geography, Autonomous University of Barcelona.

PÂRVULESCU, C. (2019). Femeile în cultura politică românească. Ce se poate aştepta de la 2019? [Women in Romanian Political Culture. What to Expect from 2019?]. Retrieved 20 December 2019, from https://adevarul.ro/news/politica/femeile-cultura-politica-romaneasca-astepta-2019-1_5c0e5345df52022f754f9820/index.html

PAUL, A. (2016). Raport privind reprezentarea femeilor în politică [Report on the Representation of Women in Politics]. Retrieved 20 December 2019, from https://cursdeguvernare.ro/reprezentarea-femeilor-in-politicaromaneasca-un-raport-actualizat-la-zi.html

PHILLIPS, A. (1995). The Politics of Presence. Oxford: Oxford University Press.

SAHU, T.K., \& YADAV, K. (2018). Women's Education and Political Participation. International Journal of Advanced Education and Research, 3(6), 65-71.

SCHNALL, M. (2013). What Will It Take to Make a Woman President? Berkeley, California: Seal Press.

SHAO, Y., LANGE, E., \& THWAITES, K. (2017). Defining Local Identity. Landscape Architecture Frontiers, 5(2), $24-41$.

SHREEVES, R., PRPIC, M., \& CLAROS, E. (2019). Women in Politics in the EU. Retrieved 20 December 2019, from http://www.europarl.europa.eu/RegData/etudes/BRIE/2019/635548/EPRS_BRI(2019)635548_EN.pdf 
STEGMAIER, M., TOSUN, J., \& VLACHOVA, K. (2014). Women's Parliamentary Representation in the Czech Republic: Does Preference Voting Matter? East European Politics and Societies and Cultures, 28(1), 187-204.

SUNDSTRÖM, A., \& WÄNGNERUD, L. (2016). Corruption as an Obstacle to Women's Political Representation: Evidence from Local Councils in 18 European Countries. Party Politics, 22(3), 354-369.

TARTAGLIA, S., \& ROLLERO, C. (2010). Different Levels of Place Identity: From the Concrete Territory to the Social Categories. In: Valentin, J., \& Gamez, L. (eds.), Environmental Psychology: New Developments (pp. 243-250). Hauppauge NY: Nova Science Publishers.

TELES, F. (2012). Local Governance, Identity and Social Capital: A Framework for Administrative Reform. Theoretical and Empirical Researches in Urban Management, 7(4), 20-34.

TERZI-BARBAROŞIE, D. (2013). Participarea femeilor la viaţa publică şi politică din Republica Moldova [Participation of Women in Public and Political Life in the Republic of Moldova]. Raport elaborat în cadrul Parteneriatului Estic de Facilitare al Consiliului Europei, Chişinău [Report elaborated within the Eastern Facilitating Partnership of the Council of Europe, Kishinev].

TIMÁR, J., \& FEKETE, É. (2010). Fighting for Recognition: Feminist Geography in East-Central Europe. Gender, Place \& Culture: A Journal of Feminist Geography, 17(6), 775-790.

TUDORA, D., BĂNICĂ, A., \& ISTRATE, M. (2015). Evaluation of Gender Disparities from the Balkan Countries. Procedia Economics and Finance, 20, 654-664.

TURCU, A. (2009). Women, Political Participation and Electoral Quotas in Romania. International Institute for Democracy and Electoral Assistance, Stockholm, Sweden.

VOINA, A.N. (2017). Reprezentarea şi discursul femeilor în politica contemporană. Studiu de caz: Romania şi Statele Unite ale Americii. Rezumatul tezei de doctorat [Women's Representation and Discourse in Contemporary Politics. Case Study: Romania and the Unites States of America. Abstract of the Ph.D. Thesis]. Sccoala Doctorală de Comunicare, Relații Publice și Publicitate, Universitatea „Babeș-Bolyai”, Cluj-Napoca [Doctoral School of Communication, Public Relations and Advertising, Babeș-Bolyai University, Cluj-Napoca].

WITTMER, E.D., \& BOUCHE, V. (2013). The Limits of Gendered Leadership: Policy Implications of Female Leadership on “Women's Issues". Politics \& Gender, 9, 245-275.

ZAMFIR, C., \& VLĂSCEANU, L. (1998). Dicţionar de Sociologie [Dictionary of Sociology]. Bucureşti: Babel. 